Article

\title{
Addressing the Sustainability Paradox: The Analysis of "Good Food" in Everyday Life
}

\author{
Andreas Exner $[$ and Anke Strüver *(i) \\ Department of Geography and Regional Science and RCE Graz-Styria, University of Graz, 8010 Graz, Austria; \\ andreas.exner@uni-graz.at \\ * Correspondence: anke.struever@uni-graz.at
}

Received: 30 August 2020; Accepted: 1 October 2020; Published: 5 October 2020

\begin{abstract}
This paper investigates food consumption in terms of socio-spatial practices as complex patterns of meanings, competencies and materialities that shape daily life. The praxeological approach that we advise might improve food sustainability policies by tackling the current sustainability paradox: persisting unsustainable food consumption despite significant media coverage of food sustainability issues and considerable political attention to this matter. Acknowledging the importance of both individual action and collective conditions in shaping food routines, we argue that the sustainability paradox might be overcome through integrating the analysis of social structures and individual behavior, and consequently addressing the determinants of sustainability in daily life. To this end, we analyze narrative interviews on "good food" regarding cultural meanings, individual competencies, and diverse materialities that govern food consumption, identify common themes and discuss their relevance for food policy. We show that food is part of complex orderings of socio-spatial practices, including embodied knowledge, patterns of commensality and constraints of orchestrating daily life, which cannot be addressed appropriately by targeting individual consumption behavior only.
\end{abstract}

Keywords: sustainable food; social practices; food policy

\section{Introduction: Food Consumption and the Sustainability Paradox}

In August 2019, the Intergovernmental Panel on Climate Change (IPCC) published a special report on climate change, land use management and food security. It provides key messages for policymakers and the agricultural sector, but also precise recommendations for individual action [1]. According to the IPCC, climate change can only be mitigated if consumption patterns are transformed on a global scale. A particularly large lever in this respect is the change in eating habits towards, among other things, more plant-based consumption. Moreover, the EAT-Lancet-Commission on Food, Planet, Health draws together aspects of health and climate sustainability in its report "Food in the Anthropocene" published in 2019 and stresses that, globally, eating habits, human health and environmental sustainability are inextricably linked [2]. Considering that "private food consumption is responsible for significant environmental impacts" [3] (p. 44) and that human nutrition causes about $30 \%$ of the total global resource consumption [4], how to change consumption patterns has to be urgently addressed [5].

Sustainable food is indeed a complex matter with many dimensions [6]. The Food and Agricultural Organization (FAO) defines sustainable diets as "those diets with low environmental impacts which contribute to food and nutrition security and to healthy life for present and future generations. Sustainable diets are protective and respectful of biodiversity and ecosystems, culturally acceptable, accessible, economically fair and affordable; nutritionally adequate, safe and healthy; while optimizing natural and human resources" [7] (p. 294). Being located on the final demand side of comprehensive 
food systems that reach from production to consumption, and involve processing, storage, package, transport, preparation and waste, diets are an important entry point for transforming food systems towards sustainability [8]. A diet is the selection of food eaten by a consumer. The composition of diets is shaped by cultural meanings, consumer competencies and materialities enmeshed in socio-spatial practices of food consumption [9]. Adopting sustainable food as a vantage point, we explore notions of "good food" by way of narrative interviews and elucidate how these are associated with practices.

Academic and societal debates on sustainable food consumption are neither new nor revolutionary (for overviews, see, e.g., [10,11]). Yet, making "good food" more sustainable is much easier said than done. Despite political declarations (see, e.g., [12]), food consumption in fact continues to be highly problematic [13]. Taking up the IPCC's objective to change patterns in food consumption, this paper therefore investigates sustainable food consumption in terms of socio-spatial practices with regard to food policy concerns. Asking how people frame "good food" within their daily routines, we aim at drawing conclusions for the development of food policy approaches that more effectively address sustainability issues beyond individualistic notions of responsibility. How to conceive of sustainable food theoretically and methodologically, we argue, has important ramifications for the type of political conclusions that may be reached, and their potential impact.

Barr et al. [14] (p. 3) emphasize that individuals are becoming more important as agents for change on the local and regional scales as environmental problems are increasingly turning into global threats. However, how individuals acquire, prepare and store food, the amount of household food waste, and what people eat cannot be understood as a private matter regarding the social and ecological conditions of production, transport, processing and packaging [6], given the impacts on livelihoods and the environment on a global scale. Unsustainable food consumption is widely accepted, however, although sustainability concerns and environmental problems are visible and well known. The limited effect of calls for sustainable food can also be observed in mobility and energy consumption. This fundamental paradox has become the subject of a variety of approaches that attempt to elucidate barriers for sustainable consumption, and to identify the conditions for change that go beyond technical measures and market mechanisms $[15,16]$.

With this study, we aim to contribute to make policies regarding sustainable food more effective. As we will argue in the following, praxeological approaches are better suited to this end than individualistic or collectivist perspectives. We thus ask, which components of food consumption practices policies should address, and what appear to be promising ways to do so. Adding to the growing, but still relatively small number of studies on food consumption practices, we provide one of the few analyses of how these relate to narrations of "good food". Starting with a discussion of four major approaches to food consumption (Sections 2 and 3), we first ask, how "good food" is understood by consumers and connected with socio-spatial practices, and, second, how these understandings and practices are related to sustainable food (Sections 4 and 5). In this way, we are able to describe a set of socio-spatial practices that make up food consumption, of which elements these practices consist in terms of meanings, competencies, and materialities, how performances of practices vary, and finally, at which points indeterminacies in performances and reflexivity occur, and, therefore, political change may be possible. The praxeological analysis will thus allow one to draw certain methodological as well as political conclusions.

\section{The Potential of Studying Consumption by Way of Practices}

Very broadly speaking, four major approaches can be distinguished regarding food consumption: quantitative social psychology, transition research, political ecology, and praxeology. They differ in how they construct the units of analysis and their relations, and consequently causality, which has repercussions on how change towards sustainability is conceived (see Table 1 for a comparison). 
Table 1. Differences between four major approaches to food consumption.

\begin{tabular}{ccccc}
\hline Approach & $\begin{array}{c}\text { Core unit of } \\
\text { Analysis }\end{array}$ & Structure & Agency & Focus of Change \\
\hline Social psychology & Individual & Context, habit & Intentions & Individual behavior \\
\hline Transition research & Institution & Regime, landscape & Innovation & Niches \\
\hline Political ecology & Class & Social domination & Interests & Power relations \\
\hline Praxeology & Practice & not applicable & not applicable & Everyday life \\
\hline
\end{tabular}

Quantitative social psychology starts from a conception of human behavior, such as food consumption, as being driven by measurable psychological factors (see for reviews, e.g., [17-19]). Transition research takes a very different look on consumption by focusing on institutions forming socio-technical regimes, broader social, cultural, technological and economic structures called socio-technical landscape, and how change of regimes and landscapes may occur through the spread of alternative socio-technical configurations that first develop in niches (e.g., [20]). Political ecology is likewise engaged in analyzing societal structures but specifically draws attention to power relations and how these are reproduced and contested by social agents [21]. Praxeology, in contrast, is concerned with behavioral patterns that are understood as collective practice, i.e., "a temporally and spatially dispersed nexus of doings and sayings" [22] (p. 89) in the sense of "a routinized way in which bodies are moved, objects are handled, subjects are treated, things are described and the world is understood" [23] (p. 250). Despite variation within each of these approaches, and certain overlaps and partial hybridizations between, e.g., political ecology and praxeology (e.g., [24]), or quantitative social psychology and transition research (e.g., [25]), they basically pursue distinct understandings of food consumption and how sustainability may be achieved [26].

Regardless of the many differences separating quantitative social psychology, transition research and political ecology, on an abstract level, they share the foundational premise of an ontological distinction between structure and agency. This distinction is reflected in specific ways in each of them; it occurs as the notion of habit and context in quantitative social psychology, in terms of regime and landscape in transition research, and as power or societal structure in political ecology. Agency is likewise conceived in different ways, ranging from individual intentions towards behavior to individual or organizational actors that attempt to achieve particular aims by innovation to classes and other groups defending their interests.

The dichotomy of structure and agency is the source of theoretical problems that stand in the way of a deeper understanding of social change, since, on the one hand, structures must be reproduced by actors, and then have no ontological status on their own (but could be reduced to agency), while, on the other hand, actors must draw on structures and operate within these in order to have agency (which then comes down to an illusory view of the reality of social life which is in fact governed by structures). Neither change nor reproduction of social life can be properly understood in this way, i.e., how unsustainable ways of consumption persist and how they may be overcome.

The paradox of a high degree of political attention and media coverage for sustainability issues, and a low impact of this knowledge on actual food consumption is addressed in different ways according to the overall epistemological approach. Most prominently, quantitative social psychology has investigated this paradox in terms of an attitude-behavior gap (e.g., [27]) that is connected with the widely applied Theory of Planned Behavior (TPB) developed by Ajzen (see [28] for a recent overview). TPB posits that behavioral intentions are the outcome of beliefs and attitudes, subjective norms and perceptions of behavioral control [28]. Although TPB is rather concerned with intentions than behavior at its core, identifying gaps between environmental attitudes and behavior, and linking these to the model of TPB, has become very influential in the literature [29]. The predictive value of quantitative social psychology for environmental behavior, and food consumption in particular, is still not fully clear. 
Unlike quantitative social psychology that is putting the individual at the center of explaining food consumption, transition research and political ecology underline structural social, cultural, economic and political conditions as governing individual action. These approaches de-emphasize the individual subject as causal agent. Transition research focuses on socio-technical innovations that are expected to shift overall structures. Therefore, slow change towards sustainability is explained on two levels: first, there are barriers to learning within niches and their alignment, and second, socio-technical regime conditions favor incumbent technologies as well as established cultural patterns and institutions. Political ecology, in contrast, critically addresses entrenched economic interests, how they achieve to build a hegemonial consensus that facilitates unsustainable behavior, and contending social movements (see [30] for an example).

Praxeological accounts take another methodological avenue. Practice-oriented studies have begun to highlight routines of action that large numbers of individuals share, which are not subject to daily deliberation, explicit negotiation or conscious decision, but serve as the groundwork for everyday life to go on in a largely unquestioned way (e.g., [31-33]). For instance, [34] (p. 15) argue that individual food consumption is not determined by conscious and rational choice, but that everyday life is tied to routines in general, and that food-related behavior is highly routinized in particular (see also [35]). In a similar vein, [36], for example, argue that food environments are important when analyzing food desires and actual consumption. Especially for children and young adults [37], the social environment plays a key role. Practice-oriented studies have moreover shown that spatial mobility routines shape food consumption, as "many consumers refrain from undertaking detours or driving extra ways solely for getting food. Instead, they try to combine pathways as much as possible" [33] (p. 13). Such routines tend to be overlooked by quantitative social psychology studies on food consumption or are outright excluded by this strand of research. Neither are they focused upon by transition research or political ecology. The authors of [38] argue that changes towards more sustainable food practices, i.e., towards enacting transition, occur in response to "fractures" in people's daily lives: social changes on an individual level, related to family and friends such as childbirth, retirement or moving house, build momentum in doing routines differently and may facilitate change. Such changes are also influenced or can be triggered by evolving societal discourse $[39,40]$. In general, change of socio-spatial practices takes place when meanings, competencies and materialities are rearticulated, i.e., the connections between elements of a practice are broken or remade [41].

Praxeology, the fourth approach to the study of consumption and change towards sustainability, suggests a way out of the structure-agency-dilemma that is implied in the approaches of quantitative social psychology, transition research and political ecology with the help of a social ontology that traverses the dichotomy between individuals, actors, or classes on the one hand, and habits/context, regimes, and power structures on the other. On this basis, praxeology is aiming to reconstruct relatively stable configurations of doings and sayings in space and time, trying to understand individuals as carriers of practices rather than their ultimate source, and scrutinizing habits, regimes and power structures in terms of these very configurations.

The praxeological perspective draws on several theoretical sources within sociology and anthropology, cultural studies, political science, and philosophy [23], and has recently been taken up in various fields of research reaching from human geography to educational studies. Despite the strong empirical concerns of praxeological debates in general, criticisms have been voiced that too much emphasis is put on theoretical considerations. Regarding methodologies, observation is often privileged as the major avenue towards a better understanding of socio-spatial practices, whereas qualitative interviews in comparison appear to be a second-best option [42-44].

Acknowledging the scarcity of praxeological studies on sustainable food consumption this article investigates food consumption by way of practices. This is necessary for potentially more effective policy interventions [45]. To this end, we will explore data gathered through narrative interviews further below. 


\section{Food Consumption as Everyday Practices}

Praxeologically speaking, consumption in itself is not a practice, but is part of multiple, intersecting practices in case that goods or services are appropriated and put to use in the course of their performance. Warde [46,47] emphasizes that eating is not a practice as such either, but a compound practice, in contrast to cooking, which is a prototypical instance of what Schatzki [22,48] calls an integrative practice. Food consumption is thus a paradigmatic case of the interlinking of practices, which has been conceptualized in different ways [42]. Not only the internal organization of practices, i.e., how materials, competencies and meanings are coupled with each other, offers leverage points for sustainability policies, but also how practices relate to each other [41,49], i.e., as randomly ordered ensembles, networks, closely linked webs or stable complexes [42].

The practice-oriented take on food consumption has the advantage to avoid the structure-agency dilemma, which is affecting the other major approaches to sustainability research $[33,46,50-53]$. By putting the collective routines of doings and sayings involved in diets into focus, praxeology circumvents to privilege either mental activities, emotions and know-how or cultural meanings such as imaginaries, norms or rules, refrains from making assumptions on internal drivers of behavior, and accounts for materiality, i.e., things, bodies, space. In this way, the analytical "black box" of societal structures, habit or context can be opened up for empirical inquiry (looking for mechanisms of change), and the complex interlocking of practices that constitutes food comes into view. Therefore, food consumption behavior is not explained by referring to intentions and motivations and related factors such as attitudes, but intentions and motivations are conceived as an intrinsic dimension of practices. Instead of asking why individuals choose certain foods, the question is how certain collective routines of doings and sayings enroll individuals and how their performance of practices varies. Theories of practice therefore "provide an important intellectual resource for understanding and perhaps establishing social, institutional and infrastructural conditions in which muss less resource intensive ways of life might take hold" [54] (p. 1). By so doing, the specific and routinized interconnections of socio-spatial arrangements, meanings and competencies that constitute practices which are enacted in primarily non-reflexive ways [35,51] are recognized as potential targets for sustainability policies. Therefore, practices are not best addressed by awareness raising campaigns focused on individual attitudes or through appealing to the rational consumer by changing price incentives [42]. This does not mean to disregard the reflexivity of consumers. However, in a praxeological view, critical reflection is put in a collective, non-individualistic context. In general, reflective thinking as well as actual rational choice are understood to be more the exception in how individuals consume goods and services rather than the rule [55].

Regarding the identification of particular practices, concerns about possible reification of practices as entities have been voiced, and warnings against a self-referential "practice architecturism" have been issued [56] (p. 32). Definitely, praxeology has to be attentive to the double dimension of practice as entity and practice as performance [22]. Practices inherently involve a normative dimension in the sense of collective understandings of "right" and "wrong" in particular socio-spatial arrangements of doings or sayings, i.e., in the course of their performance. Therefore, they also appear as practical entities of performance. "Different doings and sayings", defines Schatzki, "constitute a given practice when they express elements of the same collection of understandings, rules, and teleoaffective structure" [48] (p. 244). Practices as performance thus are characterized by a certain "leitmotif", as Jonas puts it [55].

Corresponding to the practice-oriented view, several studies investigating practices relevant for sustainable consumption by quantitative means and qualitative interviews have been published. In general, qualitative interviews are more often used than quantitative data in praxeological food consumption research (and in practice-oriented studies in general, see, e.g., [38,43,52,57]. In the following, we discuss studies combining qualitative and quantitative inquiries, since these are most promising in view of supporting sustainable food policies. 
Cheng et al. [58] analyzed changing eating practices and the socio-economic characteristics of their practitioners in the UK by using time diaries and [59] investigated drinking practices in the UK by quantitative means in order to contribute to public health policy. These studies explored the value of quantitative data for studying food consumption (including beverages), but were limited by the fact that the data themselves were not collected according to a practice framework. The authors of [45], who studied water consumption (also in the UK), gathered statistical data guided by a praxeological perspective, but did not ground their questionnaire items in a qualitative study beforehand.

In contrast, $[47,60]$ coupled qualitative interviews on eating out with a limited number of individuals with a larger scale survey and developed the questionnaire after qualitative interviews. However, they only analyzed eating out, not food consumption on the whole. The authors of [61] investigated cooking instead and also prepared a quantitative survey by qualitative interviews. A complex combination of multiple qualitative and quantitative methods was employed by [62] to dissect what they call taste regimes. Complexity has also been tackled by $[63,64]$ in a large study on what they call food styles. This study situated different food related practices ranging from the selection of diets to cooking and eating out within social groups that were defined by relatively homogeneous ways of eating. On this basis, a typology was constructed, and greenhouse gas emissions coupled with food styles were calculated. One of the important findings was that mental orientations toward sustainability do not correlate with greenhouse gas emissions of diets. In fact, those least interested in sustainability in general emitted the least greenhouse gases. Although this approach is very close to a praxeological perspective, it misses some of the nuances of the performance of practices. Moreover, this study did not investigate whether subjects interpret "good food" under sustainability aspects, and if yes, how they understand sustainable food.

Adding to this research, we will present our results on food-related practices in the following, after we have introduced our methodology.

\section{Method and Material to Study Food Consumption as Everyday Practices}

The present study on "good food" was carried out as part of interdisciplinary research on "Food Choices as Politics and Lifestyle" and "Relational Geographies of Food". Interviews had been conducted in Germany (22 interviews), in Louisiana (23) and California (43)-after which it seemed promising to focus on one more US state that can be characterized as "being in the middle", both in terms of cultural and social diversity as well as from an economic perspective. In 2017, Arizona was ranked 28 in household income, whereas Louisiana, for example, was rated 47 in household income and California 8 [65]. Arizona is a desert state and has a very dry and hot climate, especially in the summer, i.e., a considerable amount of food needs to be imported.

All interviews conducted in Germany and the US followed a similar research design for the sake of comparability and were conducted according to the same sampling procedure: The interviewees were approached on the street randomly, i.e., all people walking in or out of a food-related place on the given interview days were asked to participate. Food-related places comprised organic and conventional supermarkets, convenience stores, farmers' markets, fast-food restaurants and coffee shops, i.e., a broad variety of both venues and people. All interviews followed the same procedure: when the interviewee agreed to participate in an "eat-along-interview" (adapted from [66-69]), a quiet area nearby in a coffee shop was selected. This type of interview was chosen to focus on eating not merely as a routine practice, but to stimulate the narrative through the performance of consumption while speaking. It is worth mentioning, though, that, in general, it was challenging to encourage people to participate and that this was much easier at farmers' markets and in front of organic supermarkets than at hypermarkets and convenience stores. Apart from this unintended selection depending on the consent to take part, this is therefore a random sample, yet fortunately includes people of different age, gender, class and race as well as ways of life (see Section 5 for this variation). For this contribution, only the 23 interviews in Arizona, in different parts of Phoenix (10) and Flagstaff (13) conducted in fall 2018, are taken into account. 
Starting the interview, the participants were asked to talk about what "good food" is for them by the following narrative generating stimulus: We are interested in your personal experience with food choices. Please tell us a about your daily meals, your grocery shopping and other aspects related to food that occur to you. Feel free to also tell us about details of your everyday life and also from earlier stages of your life. Please take as much time as you'd like. During the course of the participants' stories, both immanent and exmanent questions were added when necessary (e.g., regarding daily meals, but also how good food should look like). As the interviews took place in or close to food venues, a further primer for interviewees to elaborate on their understanding of food was established. Asking about "good food" in fact addresses the teleoaffective structures of a bundle of practices that constitute food consumption. This primer not only privileges the normativity and emotional dimension of food consumption, together with instrumental ends in which regard practices connected with food are carried out. It also allows one to identify which practices or elements of practice the subjects associate with food consumption in the frame of accounting for these towards the interviewer. Integrated practices are accountable actions. Therefore, to elicit and investigate accounts of practices is a suitable way to gain a better understanding of them. However, some caveats are to be considered. First, the accounts of practices given by practitioners are mediated through societal food discourses. This provides further important information on the meanings practitioners associate with practices themselves, but should not be interpreted as being equivalent to motivations assumed to govern behavior. Second, accounts are affected by social desirability biases in relation with the interviewer. This bias reflects the influence of broader societal discourses (on, e.g., health, or being a responsible citizen), although it also stems from the normativity of practices themselves. Third, practices involve a largely unconscious stratum of doings and understandings that can hardly be accounted for by practitioners themselves, or not at all. In addition, and even more importantly, practices as performances are never identical with accounting for them, whether by practitioners or researchers. This said, the strength of our approach to analyzing qualitative interviews on a topic so strongly intertwined with societal discourses as food, lies precisely in uncovering whether food related-practices are ordered by practitioners according to a particular teleoaffective structure that governs food consumption. In this way, it also becomes evident in which way subjects conceive of food, i.e., the contours of the integrative practices constituting food. These practices may consequently be addressed by further quantitative studies aiming to inform sustainability policy. The material also allows certain insights into the broader range of practices that are interlinked with food consumption (e.g., mobility-related practices). Only in closing the narrative interview, the question on how "good food" and sustainability relate to each other in the view of subjects was tackled. Information gathered through this final question adds a further insight into the potential of food practices to incorporate sustainability concerns.

In general, interviews were analyzed in view of elements of practices and practices themselves. Socio-demographic and economic background information was in part considered for accounting for different performances.

The interview material was transcribed and then prepared for content analysis using a qualitative data analysis software (MAXQDA) [70]. Since the aim was to get more insights on food-related practices and their connection with sustainability, the main categories were developed in relation to this research objective. This step of the analysis was part of a deductive process, resulting in two main classes of categories: elements of food-related practices and statements on sustainable food. In a second step, these categories were divided inductively into several sub-categories. In the following, the results of the analysis are presented.

\section{Results: “Good Food" and Everyday Life}

In this section, we will describe the topics that our analysis has shown to be at the core of how the interviewees' accounts construct "good food". Each topic will be illustrated by anchor quotations. 


\subsection{The Salience of "Good Food": Between Reflexivity and Routinization}

To begin with, most interviewees state being conscious about their food consumption both in terms of shopping and eating practices. Regardless of gender, age, or financial background, to be conscious about one's diet is something almost all interviewees refer to and consider important, being able to provide often rich accounts of the understandings of food-related practices they have, certain rules they follow, and various ends they pursue when consuming food.

Some interviewees even explicitly point out that they care about "good food". Referring to "good food", interviewees either mention their favorite meal or a preferred type of food (such as meat, snacks etc.), or they refer to qualities such as being "fresh" or "organic". How "good food" is conceived in these accounts therefore differs substantially. This will become even clearer in the following sections that explain the specific emotions, moods and instrumental ends that subjects link to this notion. At least implicitly, "good food" was almost always connected with either health and the nutritional value of food, considerations of various aspects of one's diet in general, the environment or sustainability in a broader sense, animal welfare and the origin of food. Obviously, considerations of which food to consume, why, and how, are of particular salience in the everyday lives of most interviewees.

However, food consumption and how "good food" is practiced exhibit a high degree of routinization at the same time. The habitual character of "good food" is sometimes explicitly indicated by interviewees, especially in the case when the terms "usually" or "habit" are used to describe diets. For example, Randy and Diane refer to what they eat as follows: "But usually we just did cereal, coffee. Lunch, we usually don't go out for lunch. So, you caught us on one of those days. Usually, we just make a sandwich at home. Tuna, chicken, grilled cheese sometimes" (Section 16). Michelle and Philip briefly state that diet-related practices (e.g., making a sandwich for lunch regularly) are a "habit" (Section 432) and are learned throughout life: "You grow up on it and you do it" (Section 435). Another sort of routine relates to certain foods, mostly unhealthy foods that are chosen not too often but habitually eaten, though. Larry states that he loves pizza and they "get that once a week in the house" (Section 822). Sometimes, interviewees bring the habitual character of diets into connection with socialization. Referring to diet preferences he has learned in family and taken over from his parents, Mark thus says, "I was raised eating very balanced meals" (Section 1279), and so today he still follows the same routines.

As mentioned already, the habituality of diets does not foreclose critical reflexivity. Reconsidering their food biographies, some interviewees even explain how they shifted diets over their life course, claiming self-directed dietary change. For instance, Jacey explains that he consciously broke with some of the habits he learned from his parents: "With my childhood, oh my God, my parents, I had no idea what they were doing [ ... ]. But we ate only processed food" (Section 1177); "looking back, like as an adult, I educated myself on nutrition" (Section 1191).

\section{2. "Good Food" and Commensality: Negotiating Food and Taking Care of Others}

Subjects frequently account for social contexts, family and friends, colleagues, etc., when they speak about "good food". For instance, many of the interviewees refer to their children that they consider to be a prime motivation for a healthy family diet: "I think my kids are a big motivator of that, not wanting to add any potential harm that doesn't need to be there. So if it means I spend $\$ 7$ a gallon on milk instead of $\$ 2$ a gallon, then I'm willing to do that" (Section 695). Others consider their children's needs such as treats and snacks: "Cheese is what he really likes. And treats, ice cream and some frozen things also to make for leisure" (Sam and Sarah, Section 328). Some interviewees point out that they prefer healthy food for their children, whereas others emphasize snacks as being important to them. While the reasons for considering children's food consumption differ, their influence on how parents compose a family's diet is very obvious.

Other interviewees refer more generally to social constraints, e.g., as in the case of cooking for a (big) family (Shanoa and Barb; sections 1303 and 1316) or when a friend puts pressure on someone not 
to be too picky about food (Bernadette). In a similar way, Jacey mentions that he tends to drink water unless he is "going out with friends" (Section 1165). On those occasions, he adapts to his friends' habits.

These statements make evident that food-related practices are performances in the emphatic sense. This means that they consist of doings and sayings connected to food that are performed in front of different sorts of audiences. Doing and talking food is a public matter then. Commensality entails social control. However, there is more to it. Commensality also elicits taking care of others, as is obvious when food is prepared for relatives. On both types of occasion for commensality, negotiations about how to select diets take place, whether it is with children desiring "unhealthy" food or friends' preferences. The outcomes of such negotiations vary. In the case of parent-child relationships, parents that also refer to having a healthy lifestyle themselves are usually rather strict as compared to those who do not particularly emphasize health as being important to them and therefore let their children have treats and snacks.

\subsection{Connecting to Nature and Others: The Relationality of "Good Food"}

Food is not only put in relation with others through commensality. A further type of politicizing food in everyday life occurs through considering its non-human and human sources. In this way, Sam and Sarah as well as M.T. emphasize a close connection to nature as being the reason for consuming "good food". M.T. explains, "I think the main thing that I constantly remind myself or try to repeat out loud is, of course, 'take only what you need.' So that means living on plants" (Section 1146). She refers to a mindful way of caring for "resources". In this instance, taking care of others is realized by considering the needs of others and consequently by limiting the needs of oneself. Caring thus presumes and creates connection that is located in food. This connection does not come easily, but has to be rehearsed, i.e., by trying "to repeat out loud" a normative proposition. A specific performance of food, in this case, gives rise to a particular relationality. Rehearsing food as an object connecting self and others can be done in different ways. Sam and Sarah, to give another example, take care of plants and animals by gardening, about which they are very passionate. Again, gardening is a way to sympathize with "nature" and its "needs" and to put others' needs into relation with their own.

Food-mediated relationalities that go beyond commensality are not an exception in our material. Indeed, several interviewees explicitly refer to sustainability and voice food-related concerns that go beyond individual issues. The food these interviewees consume is assumed to affect others such as animals or local farmers in a positive way. By consuming certain foods or by consuming in a certain way, something good is given to human or non-human beings in turn. For example, Ryan says, "I don't like eating meat anymore. And the idea of, you know, something was killed to meet the demand because I wanted to eat, that kind of bugs me, you know" (Section 279). Ethical considerations, Ryan indicates, are not purely cognitive reflections, but can appear almost viscerally as something that "bugs". Similar considerations can also be described as transcending one's body. Michelle and Philip say: "I prefer buying organic because it's affecting the whole system, not just me, my body. My body is not the most important thing in this planet. How it affects an entire system down the road and how it fits into the water, how it has an effect on amphibians and reptiles and anything sensitive to water has a big impact on it. So, I definitely think there's a good reason for me to live healthy and for the planet." (Section 387). Food ethics is less of a visceral feeling in this case, but more part of a comprehensive cognitive (and maybe emotional) awareness of a web of life, which is "sensitive" (as the interviewees say in relation with water-bound animals) and thus potentially affected by one's food consumption.

Yet, another way of living the relationality of food is exemplified by Emily, who states: "I also like to support small farmers and smaller organic farms. So, sort of that consumer choice side of it and making a choice before I choose to spend my dollars is important too" (Section 943). Notably, this quotation illustrates an enhanced sense of agency couched in the terminology of choice and purchasing power that should benefit other human beings.

Overall, interviewees recurringly and strongly claim to consider sustainability when selecting diets. Sustainable food is mostly equated with organic food. The sustainability framing of food can 
even go along with subsistence production instead of food purchases. Thus, Sam and Sarah garden themselves and keep their own seeds to produce organic food (Section 356).

Although sustainable food consumption may entail higher food expenses, interviewees concerned with the relationality of food are willing to pay more for local, ethically correct or organic food. "Generally, anywhere I can, I try to buy organic. If I can afford it, that's cool" (Section 253), Ryan explains. Similarly, Sheila says, "I prefer to get organic. I know it's more expensive, but that's okay" (Section 314). Those interviewees put sustainable food in a trade-off with cheap food, as we will analyze further on in the context of valuation practices. Notably, all interviewees that account for food consumption in ethical terms have a higher education attainment than others in our sample.

\subsection{Valuating and Shopping}

Food is valued in different ways by subjects. Although interviewees were not asked about the role of price in their selection of diets, thoughts and controversies around the price of food were voiced by almost all of them, pointing out that food prices are either especially important or convenient. Interestingly, interviewees with both more or less financial means equally focus on food prices, i.e., are price conscious when purchasing food. Some interviewees state that they primarily focus on the price of foods and therefore prefer cheaper stores. Karen, for example, says, "I would say, sometimes I need to go to Safeway and get large amounts of stuff that's a little bit pricier" (Section 957). Mark emphasizes: "I usually go to Fry's. As far as price wise, they're like usually pretty close to the cheapest, which is good for me" (Section 1263). Other interviewees would rather buy less organic food because of higher prices. "I would probably lean more toward the organics if they were cheaper" (Section 44) is what Randy and Diane say in this regard. Meryl states "I don't buy a lot of organic, it's too expensive" (Section 901). In this context, Bernadette refers to the "balance between economy and health" (Section 642) that she attempts to achieve.

Price is not the only object of valuation at play in our material, but can dominate other considerations. Therefore, those interviewees who focus on the price do not consider the variety of food on offer.

Although price is mentioned by almost all subjects as important for where and what they purchase, some tend to be very much aware of the quality of food (which they call "good food", "organic" or "fresh"), the assortment and variety of foods, as well as the overall quality of the store. In fact, people with a higher income tend to underscore more the quality of food and that it is "organic" and "fresh" than those with less financial means. Nonetheless, interviewees shop at organic supermarkets regardless of monthly income. However, people with lower income rather make use of special offers in order to be able to buy organic, whereas interviewees with a higher income more consistently look out for quality.

Sheila states that she mostly shops at farmers' markets because she really likes the quality of the food there (Section 299). Others point out the freshness or the taste of foods that are offered at specific venues. For example, Lisa says, of the organic market Sprouts, "I mean, they are focusing on really bringing good products, you know, better products" (Section 715). Larry also refers to food from an organic supermarket, saying that they have "really good cheese" (Section 810). It is obvious that these interviewees either focus on freshness or organic as characteristic of "good food". Interestingly, only those interviewees that refer to buying at organic supermarkets underline specifically that qualitatively "good" and "fresh" food is important to them. Interviewees shopping at regular supermarkets do not mention any of these reasons as being important to them when talking about "good food". Sometimes, valuation involves dealing with possible contradictions between different types of value (such as price, freshness, taste, organic etc.), as has become apparent already in examples cited above.

Most interviewees highlight food quality together with the busyness or quietness of the usual food venue/s (which are both perceived as positive criteria, depending on the respondent). Some talk about the selection and variety of goods of organic supermarkets and farmers' markets, while many 
referred to supermarkets as being especially "good" and "organized", with diverse and special offers or in general providing a pleasant shopping atmosphere. For example, John says, "Whole Foods, it's just pricey but I mean you walk in the place and the way they merchandise their fruits and vegetables, it's just like, it all looks very good" (Section 1010). Interestingly, valuation practices thus are related to the valuation of the food venue as such. By purchasing food, interviewees also enter into a sensual and emotional relation with the place where food is supplied. Costumers shopping food also consume a food venue's atmosphere.

\subsection{Food and the Body: Health, Taste and Desire}

Considerations and emotions tied to sensual experience and the awareness of one's own body are recurring features of the relation to "good food" that interviewees point out. For example, some of the interviewees explain that they only eat unhealthy foods once in a while, but in general engage in healthy eating. Other interviewees explicitly refer to the relation between good food and a healthy body. Some are strict in this regard and refer very precisely to health as being their core nutritional concern. Lisa says, "Health. Overall health. Just your food is your fuel, so if you put the right things in your body, hopefully, it pays off" (Section 683). This statement entwines an instrumental view of body and food (which is equated with "fuel" like for a machine, and is conceived as "things" that are "put into" this machine-like body) with a market economy notion of "paying off", as if food were an investment and the body a type of capital. This is not the only way in which body consciousness is expressed. Intermingling health with taste and sensual appearance in terms of "being interesting", Larry explains: "I always try to find really healthy food, organic or natural, that tastes good and is interesting and is not too high on sugar and salts. That's the main thing" (Section 818). Moreover, the object of health concerns varies. Talking about "good food" and highlighting health, Meryl, for instance, refers to specific meals rather than food in general: "I think I eat pretty healthy meals. I make soup once in a while. I cook a lot of vegetables, do lots of salads, chicken salad for example" (Section 911).

References to the nutritional value of food or health are sometimes coupled with reflections on age as is apparent in the following quote from Larry: "Like, well, as I get older, well, when you're younger you can do a lot of things to yourself and the next day, you are fine. As you get older, you do one thing wrong and it can go on for a week [ ... ]. Your body is not functioning the way it did" (Section 818). Larry mentions eating burgers or a large amount of chocolate and drinking lots of wine-things his body could handle easily when he was younger.

Taste is in part fused with health considerations, as was already explained above. However, some of the interviewees mention a particular passion for certain foods, so that taste is put centerstage when talking about "good food". For example, Shaun emphasizes his love for a "big pizza and a Mexican dish" (Section 1247), while Larry refers to a similar feeling when saying that "we eat because that's the way we feel about it" (Section 842). Others emphasize the taste of food as being particularly important for how they compose their diet. For example, Sam and Sarah point out the extraordinary taste of their home-grown tomatoes: "Just the taste [ ... ]. They just taste so much better than you can buy. Even here [in Arizona] you grow your own tomatoes and they taste so much better" (Section 342).

Thirteen interviewees referred to either strong desire for "unhealthy" food or to a marked health consciousness that does, however, not match the "unhealthy" food they eat, or to inner passions for food and individual taste which contradict health concerns. In fact, health considerations and taste appear to signify two different ways of body consciousness that may enter into contradiction. However, this contradiction is not equally salient to everyone. Some of the interviewees are certain that foods they appreciate are indeed unhealthy and therefore only rarely eaten, whereas others do not restrict their diet despite some knowledge about the health implications of their preferences. For example, Frida mentions that she loves burgers because they consist of "fat and meat"; she says they are "pretty fat [ ... ] but really good" (Section 780). Later on, she emphasizes that she simply eats what she likes. Randy and Diane are aware that they do not eat particularly healthy; nonetheless, they will continue to do so: "We probably don't eat as quite as healthy as we should or could" (Section 24). Margarita refers 
to McDonald's, which is where the interview took place: "I know McDonald's is not good for you, but I am not so strict" (Section 138).

\subsection{Orchestrating Everyday Life: How Food and Mobility Interlink}

While valuation refers in part to calculations targeting price, practices related to food consumption are in fact often associated more with convenience, which is sometimes additionally put in connection with other aspects of "good food" in various ways. For instance, John would rather choose a market that is close to where he lives and in which, from his perspective, good foods are available, than choose another market that is cheaper. Additionally, James refers to an organic supermarket that was close to his home. Since it moved to another place, he has not found another organic market close by and therefore shops at regular supermarkets (Section 595). Convenience and proximity frequently seem to be more important in the accounts of subjects than the quality of food, i.e., that proximity facilitates the performance of the rhythm of daily life, for instance, by passing a shop as part of everyday routines.

In both cities, Phoenix and Flagstaff, the interviewees refer to access to supermarkets and other food outlets as being important to them. In fact, the usual site of purchase is mentioned quite often throughout the interviews. The distance between the venue where food is purchased (in most cases a supermarket) and the home or workplace is a frequent topic addressed. All people spoken to either own a car, which enables them to reach that area, live in walking distance, or have access to public transportation. Moreover, interviewees recurrently indicate how food purchasing is linked to mobility-related practices coupled with their usual organization and rhythm of everyday life.

Michelle, for example, emphasizes that she shops at different supermarkets, but she usually stops at Whole Foods on her way home (Section 376). Larry states: "So, and that's on my way to and from, from different things that I do every day. So, if I need to stop, I just stop" (Section 808). Hereby, he refers to his everyday routines, such as driving to and from the university where he works. Shanoa and her mother Barb state they would go to the store they live close to (Section 1292). "Really, it just kind of depends on whatever ... like, is closest to my house or like ... where I am staying at the time. That is typically where I shop" is what David (Section 1548) emphasizes when he was asked where he usually does his grocery shopping. It is obvious that easy (spatial) access to stores and thus the location of stores play an important role with regard to acquiring food as part of daily routines.

\subsection{Sustainability Knowledge and "Good Food"}

In an additional step, the material was analyzed with a particular focus on sustainability issues against the backdrop of our normative concept of sustainable food that we have outlined above. As we have explained in the methods part, interviewees were asked about how they understand sustainability towards the end of the interview. Most interviewees told us that they were in fact not cognizant of the ecological and social impacts of their diets. Although many referred to organic food and sustainability considerations in general, particular sustainability knowledge and a comprehensive understanding of corresponding issues were rare. Some of the interviewees mentioned controversies and insecurities when it comes to sustainability or the purchase of organic goods (e.g., with regard to labelling, the sale of fake organic goods, or overcharged price). Yet, some displayed a marked awareness or even in-depth knowledge regarding sustainability and, for example, provided information about their reading habits on that topic or about practices such as growing food themselves or reducing the amount of plastic they use.

Only those subjects that have a certain level of factual knowledge about sustainable food also point out controversies and contradictions in relation to sustainability. According to Michelle and Philip, for example, sustainability offers different perspectives and understandings: "You know, sustainable can be lots of things, so to some people it can mean organic, to some people it could mean that it pays local people. We just come from a small farm, but there's lots of different definitions of what that means" (Section 388). Philip outlines that he generally supports the concept of sustainability but is not "concerned about organic food" (Section 388). He refers to controversies about organic labels and is 
afraid that it "is again becoming more of a factory kind of mass production system that causes all kinds of problems" (Section 391). Instead of focusing only on organic production methods, he emphasizes a holistic perspective on resource use and everyday life (Section 402-418).

\section{Discussion}

Next to sustainability and "good food", our analysis resulted in six core topics that structure the accounts interviewees give of their food-related practices regarding "good food": salience, commensality, relationality, valuation and shopping, the body, and mobility. The following table (Table 2) summarizes our results and the conclusions that can be drawn regarding food policy.

Table 2. Common themes of "good food" and how they are relevant for policy.

\begin{tabular}{|c|c|c|}
\hline Themes & Aspects & Relevance for Food-Policy \\
\hline $\begin{array}{l}\text { The Salience of "Good Food": } \\
\text { Between Reflexivity and } \\
\text { Routinization }\end{array}$ & $\begin{array}{l}\text { Habit; health, nutritional value, } \\
\text { environment, animal welfare, food } \\
\text { origin }\end{array}$ & $\begin{array}{l}\text { Food behavior is routinized but } \\
\text { accessible to self-reflection that } \\
\text { should be harnessed politically; } \\
\text { heterogeneity of emotions and goals, } \\
\text { which cannot be addressed with } \\
\text { single narratives }\end{array}$ \\
\hline $\begin{array}{l}\text { "Good Food" and } \\
\text { Commensality: Negotiating } \\
\text { Food and Taking Care of } \\
\text { Others }\end{array}$ & $\begin{array}{l}\text { Social control by family, friends, } \\
\text { peers; social constraints (e.g., } \\
\text { cooking for big family); taking care } \\
\text { (especially for children) }\end{array}$ & $\begin{array}{l}\text { Food is embedded in social contexts } \\
\text { and cannot be addressed solely on } \\
\text { the level of individual consumers; } \\
\text { social embedding is negotiated } \\
\text { which offers opportunities for } \\
\text { changing food practices }\end{array}$ \\
\hline $\begin{array}{l}\text { Connecting to Nature and } \\
\text { Others: The Relationality of } \\
\text { "Good Food" }\end{array}$ & $\begin{array}{l}\text { Food seen as connection to } \\
\text { non-human and human others; as } \\
\text { means for rehearsing sustainability; } \\
\text { concern for others does not } \\
\text { necessarily involve valuation (as } \\
\text { calculative practice) }\end{array}$ & $\begin{array}{l}\text { Food-mediated relationalities } \\
\text { should be institutionalized }\end{array}$ \\
\hline Valuating and Shopping & $\begin{array}{l}\text { Price is a shared concern across } \\
\text { income levels; but other criteria are } \\
\text { important as well; enjoying } \\
\text { shopping venues is part of food } \\
\text { consumption }\end{array}$ & $\begin{array}{l}\text { Sustainable food should be } \\
\text { affordable and part of attractive and } \\
\text { accessible foodscapes }\end{array}$ \\
\hline $\begin{array}{l}\text { Food and the Body: Health, } \\
\text { Taste and Desire }\end{array}$ & $\begin{array}{l}\text { Food and body are close semantic } \\
\text { objects, but „body“ takes on } \\
\text { different meanings and is performed } \\
\text { differently through food } \\
\text { consumption and eating }\end{array}$ & $\begin{array}{l}\text { Policies for sustainable food should } \\
\text { focus on the connection with the } \\
\text { body in multiple ways }\end{array}$ \\
\hline $\begin{array}{l}\text { Orchestrating Everyday Life: } \\
\text { How Food and Mobility } \\
\text { Interlink }\end{array}$ & $\begin{array}{l}\text { Convenience of food venues is of } \\
\text { major importance }\end{array}$ & $\begin{array}{l}\text { Sustainable food must be easy to } \\
\text { integrate in daily spatial routines } \\
\text { connected with work, family life, } \\
\text { childcare, and mobility options }\end{array}$ \\
\hline
\end{tabular}

"Good food", we have argued, is a strongly salient issue in the lives of most people that we talked to. This salience is coupled with a surprisingly high degree of reflexivity regarding diets (see [71] for a similar result) — mediated through societal discourses of health, primarily, and in part of sustainability. In contrast to certain conceptions of socio-spatial practices that emphasize the unquestioned and unconscious character of practice, in our case, the arrangements of doings and sayings that constitute food consumption are routinized, but still the subject of critical reflection in the situation of the interview. This finding indicates a high level of actual or potential reflexivity connected with food-related practices, which is notable from a point of view regarding sustainable food. In fact, being conscious about shopping and eating food and relating a complex array of ends and emotions 
to these suggests that food consumption consist of doings and sayings that go beyond dispersed practices (such as standby energy consumption [72]) that are usually not perceived as practical entities of performance in people's everyday life.

Drawing together the interviews of our sample, the meaning of "good food" is substantially shaped, first, by different types of relationships. These can be actually experienced in person and be part of daily life (such as in the case of family cooking and child rearing) (see $[39,40,64]$ for similar results), or rather be imagined, e.g., relationships with a multitude of unknown non-human beings far away, but nevertheless thought to be affected by one's own food consumption. Commensality is a major dimension of food consumption according to our interviewees, which involves negotiations and taking care of others. Additionally, taking care is also performed in terms of the relationality of food. This relationality can be expressed in a variety of distinct ways, reaching from a visceral sensation of concern for animal suffering (where the body appears as the most intimate site of empathy) to a deliberate transcendence of one's body and its concerns for the sake of other forms of life (where the body is understood as the site of egoistic interests) to a notion of consumer sovereignty exerted to the benefit of small-scale farmers. Relationality can even be performed by abstaining (in part) from food purchases and shifting food-related practices radically towards subsistence.

Second, "good food" is understood in the context of shopping that includes the practice of valuation in a variety of possible performances. In this context, relationships are not directly important, but rather the relation to oneself, either by reference to financial resources, or regarding quality, health, taste and desire. Valuation is a dispersed practice that involves gathering information on certain properties, and comparing it across items, which is part of many integrative practices of social life. Valuating things includes behavior according to the model of rational choice in the sense of a definite means-end relationship, where the end is minimizing price and the means are scarce. Rational choice is a model pertaining to individual behavior, but in a praxeological perspective, it is a collective routine of doings and sayings that is related to specific materialities (e.g., supermarket shelves containing several items of closely related varieties of a certain food and purchasing food without mediation by a salesperson), meanings (e.g., the maximization of individual benefit) and competencies (e.g., memorizing prices and calculating price differences). However, valuating goes beyond rational choice in relation with scarce financial means and maximizing benefit. It can also refer to "freshness" or "organic source", or simply "quality", which are not subject to financial calculation and quantitative means-end-relations (although economists often attempt to monetize such types of valuation in their models). Taking other human beings or non-human life and the consequences of one's food consumption on others into account does not necessarily involve valuation (as a calculative practice), according to our interviews.

In our case, valuation is primarily connected with food, its price or production method. Shopping food is closely associated in some of our interviews with experiencing the food venue. In correspondence with this finding, [73] report that in a quantitative study of the effect of the spatial food environment (across and within food venues), they found a significant relation with diet.

Another type of self-relation is, third, expressed as health concern, the sensual pleasure of taste and the passionate desire that can be coupled with it. These are forms of body consciousness, where the body does not act as an instrument of empathy (as in our example above, where ethics was felt "bugging") or is rejected as a site of egoism (that is understood as unethical), but rather appreciated as a core concern to which food consumption is closely related. However, the concern with health can again take on different forms, reaching from taking care for one's children to a process akin to investing food in body capital. Therefore, health motivations for food purchases do not tell much about the actual food-related practices.

Although we did not explicitly investigate the positioning of food-related practices within wider socio-spatial arrangements of practices, it transpired in our interviews that, fourth, food consumption (and what is considered as "good food") is entangled with mobility-related practices. In line with previous research highlighting the relevance of food venue accessibility for understanding food 
consumption (e.g., [33,73], also see [71]), we found that food-related practices are orchestrated according to the overall rhythm of daily life. More significantly, however, the notion of "good food", which is often relating both to food and food venues, is frequently understood in terms of convenience. This is a strong cue for the importance of routinization in food consumption and suggests to put conscious valuation practices into proportion. To this conclusion adds our observation that patterns of commensality often shape food-related practices, and by strengthening their normativity put further constraints on change.

The material analyzed sheds light on the question whether a particular teleoaffective structure is governing practices that interviewees connect with "good food". The notion of teleoaffective structure introduced by [22,48] (which equals the component of meanings in the conceptualization of [41]) allows for going into finer detail concerning tasks and projects in relation to ends that are inscribed into doings and sayings constituting a practice. Moreover, the concept of teleoaffectivity directs attention to the relative importance of teleology and emotions or moods in the ends associated with a practice. Schatzki mentions cooking as an integrated practice that is typically low in emotional components in Western culture, while child rearing, another example for an integrated practice, is heavily imbued with affectivity [48] (p. 80). Teleoaffective structure, as we discussed already, is important for distinguishing integrative from dispersed practices. In our material, the latter one is exemplified most clearly by valuation. The topics that our interviewees were addressing concern in part differences in performance that affect the selection of food. The performance of eating is also shaped by different forms of commensality. Eating always involves certain "practices of the self", which can range from health to taste and desire. These practices are governed by different teleological and affective ends, and thus can —in part see [47]—be considered integrative practices. Further research may allow one to distinguish specific eating practices, e.g., in the sense of healthy eating, functional eating or political eating, with differing weight of emotional components in these practices. However, overall, eating appears to be best conceived as a compound practice [47]—a higher-order practice that is only loosely coordinated, regulated and institutionalized, and therefore consists of different integrative practices such as cooking, to which add dispersed practices such as valuation.

The interviews point to a range of competencies (i.e., understandings in the sense of $[22,48]$ ) that are involved in food consumption, most notably regarding health knowledge and valuation practices. However, also more mundane aspects of everyday life such as taste require embodied knowledge and are part of the manifold competencies associated with food. Additionally, sustainability knowledge also plays a certain role.

Finally, materiality is an important element of practices. The emotional components of the teleoaffective structures of food-related practices are linked to the body, which is the most important socio-spatial, material element in the practices that were the subject of the accounts of our interviewees. In the case of shopping practices, the socio-material arrangement of the food venue is explicitly appropriated in terms of sensual pleasure by many food consumers and spatiality constrains diets in connection with mobility-related practices that govern access.

In general, health is more salient to our interviewees than sustainability concerns, and it is rare that both topics are equally well considered by the subjects. Health concerns could be an important avenue for sustainability policies insofar as they correlate with ecological benefits and thus should be further investigated by statistical means. For instance, ref. [74] find that non-traditional diets, which encompass mainstream and healthy diets in their typology, are less greenhouse gas intensive than what they call traditional diets that comprise high intakes of meat, sweet foods, and fat. However, this difference is largely explained by less food intake in case of non-traditional diets. Obviously, the relations between healthy and ecological diets and how these are connected with narrations and practices merit further scrutiny.

Scholars adopting a praxeological point of view often prefer observation over interviews or quantitative methods [42-44]. Interestingly enough, one of the most important practice-oriented scholars, Pierre Bourdieu, made frequent use of both (e.g., [75]). Studying practices benefits from 
the combination of different qualitative and quantitative approaches because multi-methods designs including statistical data allow for a better description of collective regularities in doings and sayings, and facilitate the analysis of variations in performances. Since our study is limited to in-depth interviews, our results are exploratory and need to be complemented by observations of shopping, cooking, and eating practices. It should be followed by a questionnaire-based investigation that can shed light on the variability of practices and how they may be connected with socio-demographic and economic factors. Despite these limitations, one of the most significant results of our study is the fragmented character of food-related practices. Sustainable food encompasses several dimensions and reaches from food production to storage, processing, transport, packaging to cooking and waste. Interviewees that can be considered to be representative of larger swaths of people connect "good food" with only a very limited fraction of food system parts. What appears to be a holistic system in the eyes of food studies is a series of practices that do not cohere into a common performance of "good food" in the understanding of practitioners. Moreover, this insight has political repercussions to which we finally turn.

\section{Conclusions}

We have analyzed narrations of food consumption regarding possible teleoaffective structures that may govern eating as a series of normative and emotionally charged doings in specific socio-spatial settings. While narrations of "good food" comprise healthy, organic and/or affordable food, these ideas of what makes food "good" do not necessarily govern people's daily routine consumption-as the latter is also about "mood food", about caring for oneself and others, and depends on easy spatial access. We, moreover, found that such narrations are not consistent across practitioners.

This is in line with the analysis put forward by Warde, who investigated the more narrowly defined set of food-related practices called "eating", which he dissects into occasions, meals and incorporation [47]. Even when only considering eating, food-related practices appear to be not as consistently governed by a particular teleoaffective structure as an integrative practice would require. Ref. [47] rather conceives of eating as a compound practice because of the lower degree of coordination and regulation of the constituent practices. Citing the Slow Food movement, [47] illustrates that certain actors may attempt to make eating more coherent than it is actually practiced across society.

Extending this argument, and taking into account the complex character of sustainable food as it is, e.g., defined by the FAO [7] and WHO [76], eating sustainably would require to strengthen the coherence of the constituent practices of eating. Since such coherence relies more on institutionalization than on any private effort of making practices coherent in view of integrating them, food systems (including eating practices) must be made more sustainable politically, and not only by way of shifting individual food consumption. In fact, praxeology comes to a similar conclusion as political ecology in this regard. The FAO and WHO definitions of sustainable food already rule out individualistic approaches to the subject, since sustainable food has to be "culturally appropriate" and "affordable". Lending force to this argument, several interviewees indicated that their financial means constrain to opt for organic produce, and what they consider to be appropriate is shaped, inter alia, by collective meanings they attach to food.

A practice-oriented view on sustainable food gives, however, more concrete cues regarding the elements of food-related practices that have to be changed and how such change may come about (see Table 2). The close linkage between food consumption and mobility that transpired in the course of our interviews suggests that eating more sustainably requires a restructuring of everyday life in general: diversifying food venues, adapting spatial planning, improving public transport, and possibly reducing busyness in daily life in order to free time for food provisioning. Quite obviously, each of these measures requires political action and would confront power relations and entrenched economic interests. In order to achieve that corresponding policies are implemented rests on a shift in the dominant meanings of food that do not sufficiently recognize relationality, institutionalizing relationality (e.g., in terms of improved regulations and support for organic and 
fair farming), and in a more general transformation of how everyday practices interlink. Not least, it involves a change of embodied knowledge such as taste, and, notably, as an inherent part of deeply engrained modes of performing food through commensality.

Food is a field of social struggle which is particularly sensitive to politicization [77]. As our interviews have shown, many people are highly reflective about food despite the strong routinization of food-related practices. Patterns of meanings are most effectively put into question and changed into new directions by social movements precisely because they are able to politicize everyday life [78], supporting people to rehearse a more relational performance of food, and trigger the modification of practices embedded in a broader political perspective. Future studies should specifically investigate how food movement participation may contribute to a change in food consumption practices in order to broaden the empirical base for political conclusions from praxeological research.

Author Contributions: Conceptualization and methodology, A.S.; writing-original draft preparation and review and editing, A.E. and A.S.; supervision, project administration and funding acquisition, A.S. All authors have read and agreed to the published version of the manuscript.

Funding: This research was funded by Fritz Thyssen Stiftung (Cologne, Germany), grant number 10.15.2.030.SO; travel expenses for conducting the interviews in Arizona were funded by the Center for a Sustainable University, University of Hamburg (project "Sustainable Lives: Food Choices as Politics and Lifestyle").

Acknowledgments: We would like to thank Linda Meier for conducting and transcribing the interviews, and Luca Braun for editorial help. We would also like to thank Open Access Funding by the University of Graz.

Conflicts of Interest: The authors declare no conflict of interest.

\section{References}

1. IPCC. Special Report Climate Change and Land. 2019. Available online: https://www.ipcc.ch/srccl/ (accessed on 27 December 2019).

2. Willett, W.; Rockström, J.; Loken, B.; Springmann, M.; Lang, T.; Vermeulen, S.; Garnett, T.; Tilman, D.; Declerck, F.; Wood, A.; et al. Food in the Anthropocene: The EAT-Lancet Commission on healthy diets from sustainable food systems. Lancet 2019, 393, 447-492. [CrossRef]

3. Leray, L.; Sahakian, M.; Erkman, S. Understanding household food metabolism: Relating micro-level material flow analysis to consumption practices. J. Clean. Prod. 2016, 125, 44-55. [CrossRef]

4. Lukas, M.; Rohn, H.; Lettenmeier, M.; Liedtke, C.; Wirges, M.; Wiesen, K.; Schweißinger, J.; Von Lenthe, C. Assessing Indicators and Limits for a Sustainable Everyday Nutrition. In Proceedings of the System Dynamics and Innovation in Food Networks RePEc, Innsbruck-Igls, Austria, 15-19 February 2016; pp. 299-313.

5. Poore, J.; Nemecek, T. Reducing food's environmental impacts through producers and consumers. Science 2018, 360, 987-992. [CrossRef] [PubMed]

6. Johnston, J.L.; Fanzo, J.C.; Cogill, B. Understanding Sustainable Diets: A Descriptive Analysis of the Determinants and Processes That Influence Diets and Their Impact on Health, Food Security, and Environmental Sustainability. Adv. Nutr. 2014, 5, 418-429. [CrossRef]

7. Burlingame, B.; Dernini, S. (Eds.) Sustainable Diets and Biodiversity: Directions and Solutions for Policy, Research and Action, 1st ed.; FAO: Rome, Italy, 2012.

8. Meybeck, A.; Gitz, V. Sustainable diets within sustainable food systems. Proc. Nutr. Soc. 2017, 76, 1-11. [CrossRef]

9. Goodman, M.K. Food geographies I. Prog. Hum. Geogr. 2015, 40, 257-266. [CrossRef]

10. Emel, J.; Neo, H. Killing for profit: Global livestock industries and their socio-ecological implications, In Global Political Ecology, 1st ed.; Peet, R., Robbins, P., Watts, M., Eds.; Taylor \& Francis: New York, NY, USA, 2011; pp. 67-83.

11. Smith, P.; Martino, D.; Cai, Z.; Gwary, D.; Janzen, H.; Kumar, P.; McCarl, B.; Ogle, S.; O'Mara, F.; Rice, C.; et al. Agriculture. In Climate Change 2007: Mitigation. Contribution of Working Group III to the Fourth Assessment Report of the Intergovernmental Panel on Climate Change, 1st ed.; Metz, B., Davidson, O.R., Bosch, P.R., Dave, R., Meyer, L.A., Eds.; Cambridge University Press: Cambridge, UK; New York, NY, USA, 2007; pp. 497-540.

12. United Nations Sustainable Development Goals. Available online: https://sustainabledevelopment.un.org/ sdgs (accessed on 21 December 2019). 
13. Rockström, J.; Sukhdev, P. How food connects all the SDGs. 2016. Available online: https://www. stockholmresilience.org/research/research-news/2016-06-14-how-food-connects-all-the-sdgs.html (accessed on 28 October 2019).

14. Barr, S.; Gilg, A.; Shaw, G. 'Helping People Make Better Choices': Exploring the behaviour change agenda for environmental sustainability. Appl. Geogr. 2011, 31, 712-720. [CrossRef]

15. Shove, E.A. Beyond the ABC: Climate Change Policy and Theories of Social Change. Environ. Plan. A Econ. Space 2010, 42, 1273-1285. [CrossRef]

16. Brand, U.; Wissen, M. Social-ecological transformation. In The International Encyclopedia of Geography, 1st ed.; Richardson, D., Castree, N., Goodchild, M.F., Kobayashi, A., Liu, W., Marston, R.A., Eds.; John Wiley \& Sons: Hoboken, NJ, USA, 2017. [CrossRef]

17. Steg, L.; Vlek, C. Encouraging pro-environmental behaviour: An integrative review and research agenda. J. Environ. Psychol. 2009, 29, 309-317. [CrossRef]

18. Li, D.; Zhao, L.; Ma, S.; Shao, S.; Zhang, L. What influences an individual's pro-environmental behavior? A literature review. Resour. Conserv. Recycl. 2019, 146, 28-34. [CrossRef]

19. White, K.; Habib, R.; Hardisty, D.J. How to SHIFT Consumer Behaviors to be More Sustainable: A Literature Review and Guiding Framework. J. Mark. 2019, 83, 22-49. [CrossRef]

20. Geels, F.W. From sectoral systems of innovation to socio-technical systems: Insights about dynamics and change from sociology and institutional theory. Res. Policy 2004, 33, 897-920. [CrossRef]

21. Moragues-Faus, A.; Marsden, T. The political ecology of food: Carving 'spaces of possibility' in a new research agenda. J. Rural. Stud. 2017, 55, 275-288. [CrossRef]

22. Schatzki, T.R. Social Practices: A Wittgensteinian Approach to Human Activity and the Social, 1st ed.; Cambridge University Press: Cambridge, UK; New York, NY, USA, 1996.

23. Reckwitz, A. Toward a Theory of Social Practices: A development in culturalist theorizing. Eur. J. Soc. Theory 2002, 5, 243-263. [CrossRef]

24. Brand, U.; Wissen, M. The Limits to Capitalist Nature: Theorizing and Overcoming the Imperial Mode of Living, 1st ed.; Rowman \& Littlefield International: London, UK, 2018.

25. Grabs, J.; Langen, N.; Maschkowski, G.; Schäpke, N. Understanding role models for change: A multilevel analysis of success factors of grassroots initiatives for sustainable consumption. J. Clean. Prod. 2016, 134, 98-111. [CrossRef]

26. Spangenberg, J.H.; Lorek, S. Sufficiency and consumer behaviour: From theory to policy. Energy Policy 2019, 129, 1070-1079. [CrossRef]

27. Padel, S.; Foster, C. Exploring the gap between attitudes and behaviour: Understanding why consumers buy or do not buy organic food. Br. Food J. 2005, 107, 606-625. [CrossRef]

28. Ajzen, I. The theory of planned behaviour: Reactions and reflections. Psychol. Heal. 2011, 26, $1113-1127$. [CrossRef]

29. Sultan, P.; Tarafder, T.; Pearson, D.; Henryks, J. Intention-behaviour gap and perceived behavioural control-behaviour gap in theory of planned behaviour: Moderating roles of communication, satisfaction and trust in organic food consumption. Food Qual. Preference 2020, 81, 103838. [CrossRef]

30. Giménez, E.H.; Shattuck, A. Food crises, food regimes and food movements: Rumblings of reform or tides of transformation? J. Peasant. Stud. 2011, 38, 109-144. [CrossRef]

31. Head, L.; Gibson, C.; Gill, N.; Carr, C.; Waitt, G. A meta-ethnography to synthesise household cultural research for climate change response. Local Environ. 2016, 21, 1467-1481. [CrossRef]

32. Krüger, T.; Strüver, A. Narrative der ,guten Ernährung': Ernährungsidentitäten und die Aneignung öffentlicher Nachhaltigkeitsdiskurse durch Konsument* innen. Zeitschrift für Wirtschaftsgeographie 2018, 62, 217-232. [CrossRef]

33. Pfeiffer, C.; Speck, M.; Strassner, C. What Leads to Lunch-How Social Practices Impact (Non-) Sustainable Food Consumption/Eating Habits. Sustainability 2017, 9, 1437. [CrossRef]

34. Adriaanse, M.A.; Kroese, F.M.; Weijers, J.; Gollwitzer, P.M.; Oettingen, G. Explaining unexplainable food choices. Eur. J. Soc. Psychol. 2017, 48, O15-O24. [CrossRef]

35. Evans, D. Rethinking material cultures of sustainability: Commodity consumption, cultural biographies and following the thing. Trans. Inst. Br. Geogr. 2017, 43, 110-121. [CrossRef]

36. Bosco, F.J.; Joassart-Marcelli, P.; O’Neal, B. Food Journeys: Place, Mobility, and the Everyday Food Practices of Young People. Ann. Am. Assoc. Geogr. 2017, 107, 1479-1498. [CrossRef] 
37. De Cosmi, V.; Scaglioni, S.; Agostoni, C. Early Taste Experiences and Later Food Choices. Nutrients 2017, 9, 107. [CrossRef]

38. O'Neill, K.; Clear, A.; Friday, A.; Hazas, M. 'Fractures' in food practices: Exploring transitions towards sustainable food. Agric. Hum. Values 2019, 36, 225-239. [CrossRef]

39. Brunner, K.M. Nachhaltiger Konsum-Am Beispiel des Essens. SWS Rundschau 2009, 49, $29-49$.

40. Kropp, C.; Brunner, K.M. Ökologisierungspotentiale der privaten Konsum- und Ernährungsmuster. MPS. Diskussionspapier Nr. 1, BMBF research project Von der Agrarwende zur Konsumwende? Bundesministerium für Bildung und Forschung: München, Germany, 2004.

41. Shove, E.; Pantzar, M.; Watson, M. The Dynamics of Social Practice: Everyday Life and How it Changes; SAGE Publications: Los Angeles, CA, USA, 2012.

42. Jonas, M.; Littig, B. Sustainable Practices. In International Encyclopedia of the Social and Behavioral Sciences, 2nd ed.; Wright, J.D., Ed.; Elsevier: Oxford, UK, 2015; pp. 834-838. [CrossRef]

43. Nicolini, D. Articulating Practice through the Interview to the Double. Manag. Learn. 2009, 40, $195-212$. [CrossRef]

44. Schmidt, R. Sociology of Social Practices: Theory or Modus Operandi of Empirical Research. In Methodological Reflections on Practice Oriented Theories, 1st ed.; Jonas, M., Littig, B., Wroblewski, A., Eds.; Springer: Cham, Switzerland, 2017; pp. 3-17.

45. Browne, A.L.; Pullinger, M.; Medd, W.; Anderson, B. Patterns of practice: A reflection on the development of quantitative/mixed methodologies capturing everyday life related to water consumption in the UK. Int. J. Soc. Res. Methodol. 2013, 17, 27-43. [CrossRef]

46. Warde, A. What sort of practice is eating. In Sustainable Practices: Social Theory and Climate Change, 1st ed.; Shove, E., Spurling, N., Eds.; Taylor and Francis: London, UK; New York, NY, USA, 2013; pp. 17-30.

47. Warde, A. The Practice of Eating, 1st ed.; Polity: Cambridge, UK, 2016.

48. Schatzki, T.R. The Site of the Social: A Philosophical Account of the Constitution of Social Life and Change, 1st ed.; Penn State University Press: University Park, PA, USA, 2002.

49. Spurling, N.; McMeekin, A.; Shove, E.; Southerton, D.; Welch, D. Interventions in Practice: Re-Framing Policy Approaches to Consumer Behaviour; Sustainable Practices Research Group Report: Manchester, UK, 2013.

50. Warde, A. Consumption and Theories of Practice. J. Consum. Cult. 2005, 5, 131-153. [CrossRef]

51. Warde, A. After taste: Culture, consumption and theories of practice. J. Consum. Cult. 2014, 14, $279-303$. [CrossRef]

52. Sahakian, M.; Wilhite, H. Making practice theory practicable: Towards more sustainable forms of consumption. J. Consum. Cult. 2013, 14, 25-44. [CrossRef]

53. Keller, M.; Halkier, B. Positioning consumption. Mark. Theory 2013, 14, 35-51. [CrossRef]

54. Shove, E.; Spurling, N. Sustainable practices: Social theory and climate change. In Sustainable Practices: Social Theory and Climate Change, 1st ed.; Shove, E., Spurling, N., Eds.; Taylor and Francis: London, UK; New York, NY, USA, 2013; pp. 1-13.

55. Jonas, M. Nachhaltigkeit und Konsum-Eine praxissoziologische Kritik. In Praxistheorie: Ein Soziologisches Forschungsprogramm, 1st ed.; Schäfer, H., Ed.; Transcript: Bielefeld, Germany, 2016; pp. 345-364.

56. Nicolini, D. Practice Theory as a Package of Theory, Method and Vocabulary: Affordances and Limitations. In Methodological Reflections on Practice Oriented Theories; Jonas, M., Littig, B., Wroblewski, A., Eds.; Springer: Cham, Switzerland, 2017; pp. 19-34.

57. Hitchings, R. People can talk about their practices. Area 2011, 44, 61-67. [CrossRef]

58. Cheng, S.-L.; Olsen, W.; Southerton, D.; Warde, A. The changing practice of eating: Evidence from UK time diaries, 1975 and 2000. Br. J. Sociol. 2007, 58, 39-61. [CrossRef]

59. Ally, A.K.; Lovatt, M.; Meier, P.S.; Brennan, A.; Holmes, J. Developing a social practice-based typology of British drinking culture in 2009-2011: Implications for alcohol policy analysis. Addiction 2016, 111, 1568-1579. [CrossRef]

60. Warde, A.; Martens, L. Eating Out: Social Differentiation, Consumption and Pleasure, 1st ed.; Cambridge University Press: Cambridge, UK, 2000.

61. Van Kesteren, R.; Evans, A. Cooking without thinking: How understanding cooking as a practice can shed new light on inequalities in healthy eating. Appetite 2020, 147, 104503. [CrossRef]

62. Arsel, Z.; Bean, J. Taste Regimes and Market-Mediated Practice. J. Consum. Res. 2013, 39, 899-917. [CrossRef] 
63. Stieß, I.; Hayn, D. Ernährungsstile im Alltag: Ergebnisse einer repräsentativen Untersuchung. Ernährungswende Diskussionspapier Nr. 5; ISOE: Frankfurt on the Main, Germany, 2005.

64. Eberle, U.; Hayn, D.; Reehag, R.; Simshäuser, U. (Eds.) Ernährungswende: Eine Herausforderung für Politik, Unternehmen und Gesellschaft, 1st ed.; Oekom verlag: München, Germany, 2006.

65. Suneson, G. Wealth in America: Where are the richest and poorest states based on household income? 2018. Available online: https:/eu.usatoday.com/story/money/economy/2018/10/08/wealth-america-householdincome-richest-poorest-states/38051359/ (accessed on 20 August 2020).

66. Carpiano, R.M. Come take a walk with me: The "Go-Along" interview as a novel method for studying the implications of place for health and well-being. Heal. Place 2009, 15, 263-272. [CrossRef] [PubMed]

67. Kusenbach, M. Go-Alongs, In Qualitative Data Collection; Flick, U., Ed.; Sage: London, UK, 2018; pp. $344-361$.

68. King, A.C.; Woodroffe, J. Walking Interviews. In Handbook of Research Methods in Health Social Sciences; Liamputtong, P., Ed.; Springer: Cham, Switzerland, 2017; pp. 1-22. [CrossRef]

69. Thompson, C.; Reynolds, J. Reflections on the go-along: How "disruptions" can illuminate the relationships of health, place and practice. Geogr. J. 2018, 185, 156-167. [CrossRef]

70. Mayring, P. Qualitative Content Analysis. Theoretical Foundation, Basic Procedures and Software Solution. Social Science Open Access Repository SSOAR. 2014. Available online: https://nbn-resolving.de/urn:nbn:de: 0168-ssoar-395173 (accessed on 30 November 2019).

71. Vermeir, I.; Verbeke, W. Sustainable Food Consumption: Exploring the Consumer "Attitude-Behavioral Intention" Gap. J. Agric. Environ. Ethic- 2006, 19, 169-194. [CrossRef]

72. Gram-Hanssen, K. Standby Consumption in Households Analyzed With a Practice Theory Approach. J. Ind. Ecol. 2009, 14, 150-165. [CrossRef]

73. Gustafson, A.; Christian, W.; Lewis, S.; Moore, K.; Pitts, S.J. Food venue choice, consumer food environment, but not food venue availability within daily travel patterns are associated with dietary intake among adults, Lexington Kentucky 2011. Nutr. J. 2013, 12. [CrossRef] [PubMed]

74. Asvatourian, V.; Craig, T.P.; Horgan, G.; Kyle, J.; MacDiarmid, J. Relationship between pro-environmental attitudes and behaviour and dietary intake patterns. Sustain. Prod. Consum. 2018, 16, 216-226. [CrossRef]

75. Bourdieu, P. La Distinction. In Critique Sociale du Jugement; Les Éditions de Minuit: Paris, France, 1979.

76. WHO. Information sheet: A healthy diet sustainably produced. Available online: https://apps.who.int/iris/ bitstream/handle/10665/278948/WHO-NMH-NHD-18.12-eng.pdf?ua=1 (accessed on 23 December 2019).

77. Figueroa, M. Food Sovereignty in Everyday Life: A People-Centered Approach to Food Systems. In Food Sovereignty: A Critical Dialogue. In Proceedings of the International Conference Yale University, New Haven, CT, USA, 14-15 September 2013. Conference Paper No. 44.

78. Jonas, M. Transition or transformation? A plea for the praxeological approach of radical socio-ecological change. In Praxeological Political Analysis, 1st ed.; Jonas, M., Littig, B., Eds.; Springer: Cham, Switzerland, 2017; pp. 116-133.

(C) 2020 by the authors. Licensee MDPI, Basel, Switzerland. This article is an open access article distributed under the terms and conditions of the Creative Commons Attribution (CC BY) license (http://creativecommons.org/licenses/by/4.0/). 